\title{
THE RESORTS OF CROATIA IN THE LIFE AND MULTIFACETED ACTIVITIES OF IVAN FRANKO
}

\section{Halyk V. M.}

\section{INTRODUCTION}

The outstanding figure of Ivan Franko always was and continues to be the subject of interest not only for Ukrainian, but also foreign scholars. This is evidenced by the fact that many of Ivan Franko's works have been translated into different languages, in many states the name of a prominent Ukrainian scholar is being renewed, museums, memorial tables and, finally, memorials are opened in different cities related to his stay there. In this context, let us look at the Croatian city Lypyk, where on March 10, 2011 a monument to Ivan Franko was opened. This is connected with the fact that the scholar underwent a course of treatment between late March and early April of 1908. While being in Lypyk, I. Franko was actively involved in scientific activities: he studied literature there, was interested in local folklore, wrote poems and reviews.

There is also the second resort town of Croatia, Lovran, which, like the previous one, was the site of Ivan Franko's regular treatment. It was here that the scholar spent almost a month (the beginning of March - the beginning of April 1909), where he underwent a course of treatment in a famous local doctor, Doctor of Medicine at the University of Vienna A. Eder.

Both in Lypyk and Lovran I. Franko, despite the ban of doctors, was engaged in scientific activity. Most of the time he was interested in the works of well-known Slavonic researchers and made translations of their works. It should be noted that the doctors allowed him to be engaged in easier scientific activities. That was the translation: scholar has translated a number of works of culture.

Looking at the creativity of the scholar of this time, we see that he was worried about his disease, but tirelessly fought with it, sometimes even in strange ways. In fact, from that moment on in the life of Ivan Franko, a kind of the beginning became the end, from 1908 to 1916 (almost 8 years) he was attacked by constant mental disorders, nervous 
breakdowns, which, of course, influenced scientific activity. Although the disease receded from time to time, and then escalated again, that period of life was for the scholar not only years of severe pain and suffering, but also fruitful creative work.

\section{Ivan Franko and Lypyk}

Croatian city Lypyk primarily known as a health spa resort on a European area. Here I. Franko was on the recovery from the second half of March to the first half of April 1908. The reasons for this trip are learned from the memories of M. Mochulskyi, who writes that before Christmas in 1908 he visited I. Franko with the purpose of borrowing several books for work. However, at that time he did not notice that the scholar had health problems, but when he visited him a second time, at the end of February 1908, he saw him lying "in his bedroom on a bed", undressed and easily covered with a blanket. When the visitor entered the room, Franko jumped out of the bed and sat down on it. During the conversation he complained of "frequent migraine attacks", which rarely lasted for several days, "a left hand aches very much that he cannot sleep because of it". I. Franko mentions about his illness in the article "History of my illness", where he says that at this time he felt completely exhausted, he suffered headache and ringing in his ears twice a week, because of which he was forced to see a doctor ${ }^{2}$. F. Vovk was reported on his poor state of health on February 20, 1908: “... I am broken by a serious illness, now I cannot think..."”3.

Ivan Franko was treated by Lev Kossak. He had been taking care of his health for many years, but stressed that his patient was very disrespectful and disobedient ${ }^{4}$. During the treatment, I. Franko had to

${ }^{1}$ Мочульський М. 3 останніх десятиліть життя Івана Франка (1896-1916): Гнатюк М. упор. Спогади про Івана Франка. Львів: Каменяр, 1997. С. 439-440.

2 Франко I. Історія моєї хвороби: Інституту літератури ім. Т. Г. Шевченка НАН України (далі - І. Л.). Ф. 3. Спр. 185.; Франко І. Історія моєї хвороби / Публікація Ярослави Мельник: Парадигма / Інститут українознавства НАН України. Львів: Критика, 1998. С. 179.; Мельник Я. I остання часть дороги... Іван Франко: 1908-1916. Дрогобич, 2006. С. 385.

${ }^{3}$ Франко І. Лист до Ф. К. Вовка від 20 лютого 1908 р. із Львова: Франко І. Зібрання творів у 50-ти т. (далі - Франко І. Зібр. тв.). К., 1986. Т. 50. С. 351.

${ }^{4}$ Мочульський М. Іван Франко: Студї̈ та спогади. Львів, 1938. С. 149. 
follow a diet, he was forbidden to read and write ${ }^{5}$. In a letter to M. Hrushevskyi, the scholar writes that his "health... has deteriorated a bit. There is something behind the cerebellum, the center of pain in the size of a silver guilder and not giving back, as if in a hold. I am competing and holding on and doing something, not counting the pressure of my head"6.

But at this time, when I. Franko decided to use the services of a physician, the treatment was ineffective, so L. Kossak advised the scholar to refrain from work, but not to be bored, he allowed to do translations ${ }^{7}$ and, finally, "to go to Lypyk to be treated with iodine water". In the second half of March 1908, I. Franko began to travel ${ }^{8}$. Before leaving visited the council meeting of the Scientific Society of Shevchenko, where he edited the second volume of "Galician-Ruthenian folk prypovidky"9. According to M. Hrushevskyi, on March 21, 1908, I. Franko went on a journey to Croatian town-resort Lypyk in "full consciousness, with busy plans and then announce about plans" ${ }^{10}$. When he went there, he arranged with V. Hnatyuk that he would translate the shameful materials he had collected over several years and took with him over a hundred of stories ${ }^{11}$.

I. Franko arrived in Lypyk on March 24, 1908. In his letter to M. Hrushevskyi, he wrote that he had safely stopped in and started a medical examination. In the context, we would like to emphasize that the letter of Ivan Franko to M. Hrushevskyi, which was submitted in volume 50 of Ivan Franko's works under number 342, had an error in the date of the letter, it was dated June 1908, from Lypyk, and the note of "The Dilo" newspaper No. 87 dated April 18, 1908, it is known that the scholar had already returned from Lypyk by this time, namely,

${ }^{5}$ Франко І. Лист до М. С. Грушевського від [першої половини квітня 1908 р. із Липика]: Франко І. Зібр. тв. Т. 50. С. 355.

6 Там само.

7 Гнатюк В. Франко в Липику: Іван Франко у спогадах сучасників / Упоряд. передмова та примітки О. І. Дея. Львів, 1972. Кн. II. С. 247.

${ }^{8}$ Мочульський М. 3 останніх десятиліть життя Івана Франка (1896-1916)... C. 440 .

9 Там само.

${ }^{10}$ Грушевський М. Недуга д-ра Івана Франка: Літературно-науковий вістник. Львів - Київ, 1908. Т. XLII. Кн. V. За май. С. 405.

${ }^{11}$ Гнатюк В. Франко в Липику... С. 247. 
April 16, 1908, after which he was undergoing treatment at Svitalskyi sanatorium in Lviv. At the time of arrival, the weather in the city was bad, but the medical staff was good for I. Franko and encouraged him to recover. Further, he asks M. Hrushevskyi: "Please send me those initial cards of the theological article that I have left at yours', and I will shortly send you its completion, and maybe another one, because there is nothing else to do here. I do not think of the original creativity, and it is not time before the spring opens. Today I started the fonts, but I still can't feel the result, my arm hurts awfully"12. At the end of the letter, he noted that he had the intention to get acquainted with the local "scientific circle",

Before the end of March, I. Franko sends a postcard with "obrazok" (a picture) of landscapes of Lypyk to his daughter. Here he writes: "Dear Gandzya (Anna). Here are the pictures from Lypyk if someone does not steal on the way. You do not think that here the scenery is so beautiful as in the pictures. Trees, like those on pictures, are still bare, it is cold outside as at home, and there is nobody and nothing interesting in the streets. The tiny houses and the beautiful villas between them are now empty. That's when it is warm, there will be a lot of parishioners, it will not be so, but I hope to be ready and leave by the time" 14 .

March 31, 1908 I. Franko writes to his doctor L. Kossak the response to the received letter on that day, in which, he questioned him how his treatment went on ${ }^{15}$. Sincerely thanking him for the correspondence, he notes that he was very comforted by it, and describes the treatment: "I drink iodine water early and in the afternoon a quarterliter [in] 3 glasses, 3 or 4 glasses at a time, of course, with stops. I started doing massages on Sunday" ". As we can see, Ivan Franko was

12 Франко І. Лист до М. С. Грушевського від 24 березня 1908 р. із Липика: Франко І. Зібр. тв. Т. 50. С. 351-352.

13 Там само. С. 352.

14 Франко-Ключко А. Рукопси Івана Франка в Канаді: Для Тебе Тату / Упоряд, автор вступної статті й копентарів М. Шалата. К., 2010. С. 245.; Франко-Ключко А. Рукописи Івана Франка в Канаді: (Лист із Липика, Югославія, та інше). Вінніпег, 1957. URL: http://library.kr.ua/elib/franko/franko-rukopis.html.

${ }^{15}$ Коссак Л. Лист до І. Франка від 31 березня 1908 р. із Львова. І. Л. Ф. 3. Спр. 50. С. 352-353.

${ }^{16}$ Франко І. Лист до Льва Коссака від 31 березня 1908 р. із Липика: Франко I. Зібр. тв. Т. 50. С. 352. 
massaged by a professional massage therapist, who was a very pleasant man, a Croat by nationality, serving in Galicia, where he was interested in Galician affairs. I. Franko spoke with him in German. As for his state of health, he states: "... the hand does not hurt no longer. I put it twice in hot iodine water right here at the source, and it does very well for me. In the bath the water is a little too cold for me, $30^{\circ}$ in the pouring wave, but quickly gets cold. I asked the doctor to give me warmer up to $35^{\circ}$, and it seems to me that it will bring my recovery faster". I. Franko lived here alone in a small room, the owner of which was Pavlyachek ${ }^{17}$.

The same day, answering to his wife's letter, I. Franko tells in detail about his treatment, the story is relevant to the story for L. Kossak), where he lives, and asks if his daughter Anna received a postcard with a large view of Lypyk"18. The husband further asks his wife to send him "a leaflet with an extract from "The life of Vasil the New" from Keltuyala". In addition, he notes that "every night" he talks to "Celina she is, certainly, in Drohobych. We speak in a sleep, via spirit's mail. This is where this mail brings me interesting news, including from Domanitskyi. Because of her, I was at Shevchenko organization's meeting tonight in St. Petersburg" "19. This shows that the state of the scholar worsened, he was pursued by chimeras.

Olga Franko fulfilled the request of her husband, which we learn from a letter to her on April 6, 1908 from Lypyk: "Dear mother! Your beloved letter I added to the letter of Keltuyala, I got it at night, and I answer now, because I am very depressed by my illness and have no hope in my life any further" 20 . From the letter we see that the scholar does not know how much longer he will be treated in Lypyk. He predicted it could be a week or even two. Apparently, the wife reported that the family lacked money for housing, as I. Franko tells her to contact V. Hnatyuk, or to send his son Andrew to him and asked him to write for I. Franko "A cheque for a sum of money" his wife would needed to live on until Franko's return from Lypyk ${ }^{21}$.

17 Там само.

18 Франко I. Лист до О. Ф. Франко від 31 березня 1908 р. із Липика: Франко I. Зібр. тв. Т. 50. С. 353.

19 Там само.

${ }^{20}$ Франко І. Лист до О. Ф. Франко від 6 квітня 1908 р. із Липика: Франко I. 3ібр. тв. Т. 50. С. 353-354.

${ }^{21}$ Там само. С. 354. 


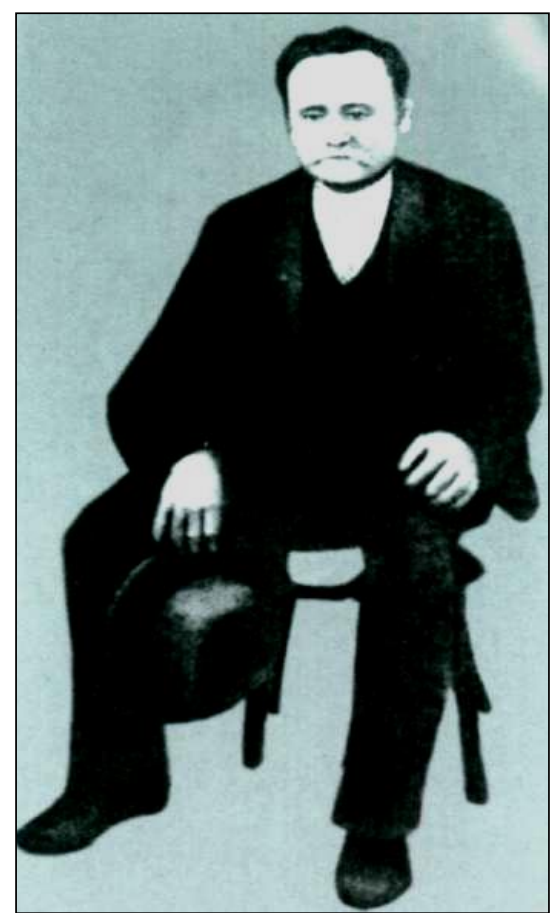

\section{Ivan Franko during the therapy treatment. The end of March - the beginning of April 1908}

The next day, Ivan Franko again wrote to his wife: "I was in such disarray yesterday and oppression that have forgotten to put into thy letter this list to Mr. Keltuyala in St. Petersburg". As for his health, he says he had a visit to a doctor Braithweiser, who said it would take three or four more weeks for treatment ${ }^{22}$. Already on April 8, this year, his wife wrote off to her husband who had a hope for an early meeting, that she would take money in the Credit Union, and about his health, she said: "Why are you so worried about your weakness? Remember, in Zavadiv 10 years ago, you were the one who was oppressed and hoped for a speedy death. And thanks God, we lived in peace. But everything is in the hands of God... "23.

However, the worries of Ivan Franko were not without grounds. The treatment in Lypyk did not go for good. His daughter writes in her memoirs that his hope of soon recovery has not been fulfilled. Soon the family receives a telegram from the resort, which stated that Franko is in a bad state and needs to be taken home, as did his son Taras. But despite

${ }^{22}$ Там само.

${ }^{23}$ Франко О. Лист до І. Франка від 8 квітня [1908 р.] зі Львова. І. Л. Ф. 3. Спр. 1636. С. 37-38. 
the fact that the scholar was seriously ill and suffered from the relentless paralysis of his hands, he still continued to write, and nothing but poems. Unfortunately, they had an immoral content, so Taras burned them in Lypyk ${ }^{24}$. The translations of stories, which Ivan Franko took from V. Gnatyuk were burned as well ${ }^{25}$. About immoral content of the poems also mentions in his memoirs E. Chykalenko who writes that the scholar sent him to "The "Rada" two poems about academic Veselovskyi, and they were so immoral that even could not be read aloud, they were too "pornographic" for publishing ${ }^{26}$.

Here, perhaps, the scholar's worldview was influenced by hallucinations, which were reflected in the story "Big Noise", which contained a hallucinatory-romantic elements and shameful words $^{27}$. Taking that into account, the publishing house of "LiteraryScientific Herald" in the publication of the work in 1908 made some adjustments $^{28}$.

However, not all of Ivan Franko's works from Lypyk were extremely bad. M. Mochulskyi recalls that they, together with V. Hnatyuk, went to visit the Franko's family and see if any manuscripts had been brought from Croatia. They were told that all the manuscripts had been burned by his son Taras in Lypyk at the request of I. Franko himself. However, looking through one of the books the scholar had with him, he found three "poetry books" on a sheet of white paper. These were: "Though you will forget me ...", "You call me again, my goddess", "Honor to the creator of creatures" (excerpt), and they could be "called the poet's swan song", Having read poetry aloud, M. Mochulskyi and V. Hnatyuk were very fond of them, especially the first one. Even Franko's wife, when she heard the poetry "Although you will forget about me ..." rejoiced, thinking that her husband had written it for her.

${ }^{24}$ Франко-Ключко А. Рукопси Івана Франка в Канаді... С. 245.

${ }^{25}$ Гнатюк В. Франко в Липику... С. 247.

26 Чикаленко Є. Іван Франко: (Уривок із споминів): Наша громада. 1926. Кн. 5-6. С. 17.

${ }^{27}$ Мочульський М. Іван Франко: Студї та спогади. Львів, 1938. С. 129.

${ }^{28}$ Франко I. Зібр. тв. Т. 22. С. 507-508.

29 Мочульський М. 3 останніх десятиліть життя Івана Франка (18961916)... C. 387. 
However, according to M. Mochulskyi, it was not devoted to Franko's wife, since when he reprinted itr in the collection "Ancient and new", he gave it the title "To unnamed Mary" 30 . The poetry written by Ivan Franko in Lypyk, were printed on the pages of "The LiteraryScientific Herald" and "The Memoirs of the Shevchenko Scientific Society", that was evidenced by Myhailo Grushevskyi ${ }^{31}$.

About hallucinations and visions in Lypyk I. Franko told the correspondents. These stories were impressive. In particular, in a letter to F. Vovk dated April 2, 1908, he complained that nightmares disturbed him at night and did not allow him to sleep at all, or flooded him in a hot dream and very tormented his soul: "Even now, my health is not very wise, but, most of all, my soul and thinking are so sluggish, exhausted, dull and grieving that I can't even think of any, at least a little original work. It's just that the pen falls out of my hands, and when I write in connection a few words, I will probably miss a few letters and the nonsense comes out ${ }^{\text {"32 }}$.

Taking care of this state, Franko tried to drive away from endless visions, but, as he says, some invincible force overtook them again and again. Unable to explain it, he sought help from others. So, saying to W. Domanytskyi how one night in a dream he had read the letter, addressed to Scientific Society of Taras H. Shevchenko in Lviv, and even some article by an unknown author, which was directed against him personally and asked to inform the recipient, if this may be true ${ }^{33}$. I. Franko insisted on the answer, as he needed it badly to make sure that he was dealing with hallucinations or with the first manifestations of madness ${ }^{34}$. In this connection, I. Franko begins to believe that he receives the gift of communicating through the mail of spirits ${ }^{35}$.

${ }^{30}$ Tам само.

${ }^{31}$ Грушевський М. Недуга д-ра Івана Франка... С. 405.

32 Франко І. Лист до Ф. К. Вовка від 2 квітня 1908 р. з Липика / Публікація Ярослави Мельник: Парадигма. Зб. наук. праць / Ін-т українознавства ім. І. Крип'якевича НАН України. Львів, 1998. С. 189-190.

${ }^{33}$ Франко І. Лист до В. Доманицького від 27 березня 1908 р. з Липика / Публікація Ярослави Мельник: Парадигма. Зб. наук. праць / Ін-т українознавства ім. І. Крип’якевича НАН України. Львів, 1998. С. 183-185.

${ }^{34}$ Там само. С. 185.

35 Франко І. Лист до О. Ф. Франко від 31 березня 1908 р. із Липика: Франко І. 3ібр. тв. Т. 50. С. 353. 
On April 2, 1908, I. Franko wrote again to Domanitskyi, where he reports: "As for my life in Lypyk, I do not think that I will be here by the end of April, as I will only finish the course of treatment given by my doctor, I will leave home from now on, I will not do there anything new, especially in fiction, because I do not feel no strength, but I will continue to lead my own parables and the publication of apocryphal and narrative literature, and the relevant scientific works on the topic of interest for me... Life in Lypyk is very cheap and quite good, cheap wine of own production, light and very good, liter costs one krona and is drunk well and does not harm anything. Time is not special here; the last days of March and the first of April are quite cold and uninviting and no better than ours in Eastern Galicia"36.

In the article "History of my illness" I. Franko tells about one of such conversations, which ended for him tragically. A fantastic accident occurred in Lypyk when he lay in a fever the night 7 to 8 April 1908. As he said he was awaken by spirits and was commanded to exit the chambers, and then drove the road that led to the field and threatened with death and forced to get undressed. When he was only in his shirt, the spirits commanded him to get off the road, go over the ditch, climb over the raft, and then drive on to the meadows. There he was driven from puddle to puddle, forbidden to return to Lypyk. Finally, Franko was tried and sentenced to hell, and before that he had to be imprisoned on some mountain for 18,000 years. Some time after, the souls of the late I. Naumovich and I. Galushevich appeared before him, made reproaches to him, and finally, left in the midst of the swamp for the lime of this road. Here, in fear, Franko stayed until 10 o'clock in the morning, and was found by a gendarme Tarnavskyi, who lived near him. The disappearance of I. Franko from Pavlyachko's chamber made a fright, and he was sought until the morning ${ }^{37}$. Some scenes from

${ }^{36}$ Франко І. Лист до В. Доманицького від 2 квітня 1908 р. з Липика / Публікація Ярослави Мельник: Парадигма. Зб. наук. праць / Ін-т українознавства ім. І. Крип’якевича НАН України. Львів: Класика, 1998. С. 187.

37 Франко I. Історія моєї хвороби / Публікація Ярослави Мельник: Парадигма... С. 180-181. 
"History of my illness" Franko placed in the story "Cross paths"38 and the poem "Funeral" 39 .

I. Franko also told V. Hnatyuk about that incident in a letter dated April 10, 1908. We also learn from the letter that during this adventure he lost his clothes, a purse with money (about 185 crowns) and a watch. However, soon the clothes was found, and the rest - no. Therefore, he asked V. Hnatyuk to send him 200 crowns, since he had to pay for the services provided. Concluding the letter, I. Franko said: "Tell my wife of my adventure and reassure her whenever possible. Apart from the material loss, thank God, it did not seem to bring harm to my health"40.

The fact that Ivan Franko was in Lypyk in a serious condition was also reported by "The Dilo" newspaper on April 11, 1908. In particular, the Novelties section stated that Dr. Ivan Franko, who had been ill for a long time, left three weeks ago on the advice of a doctor in a Kupel area in Lypyk Slavonia. Two days ago, the patient's condition worsened so much that he was transported to the neighboring area of Pankrat, to the hospital. Yesterday the son Taras went to the sick..." ${ }^{41}$. A week later, April 18, "The Dilo" informed that health of I. Franko did not improve, he came to the city with his son Taras on 16 April and is being treated in a sanatorium of Dr. S. Svyontovskyi ${ }^{42}$.

The first days of hospital stay, no visitors were admitted to I. Franko. Often, medical staff complained about the patient because he did not want to follow the advice of doctors, ran away from the sanatorium ${ }^{43}$. On April 28, "The Dilo" newspaper appealed to the residents of Lviv and its suburbs with the request of the sanatorium doctors not to visit the patient, since he only needed peace ${ }^{44}$. Ivan Franko stayed at the hospital for three months, but his condition did

${ }^{38}$ Франко I. Перехресні стежки: Франко I. Захар Беркут. Перехресні стежки. Оповідання. К., 2006. С. 177-462.

39 Франко І. Епілог: Франко І. Похорон. Поема. Львів, 2008. С. 52-54.; Франко I. Епілог: Франко I. Похорон: Франко I. Зібр. тв. Т. 5. С. 87-89.

${ }^{40}$ Франко І. Лист до В. Гнатюка від 10 квітня 1908 р. з Липика / Публікація Ярослави Мельник: Парадигма. 3б. наук. праць / Ін-т українознавства ім. І. Крип'якевича НАН України. Львів, 1998. С. 191-192.

${ }^{41}$ Новинки: Дїло. Ч. 81.11 цьвітня. Львів, 1908. С. 3.

${ }^{42}$ Новинки: Дїло. Ч. 87. 18 цьвітня. Львів, 1908. С. 3.

${ }^{43}$ Мочульський М. Іван Франко: Студї та спогади... С. 156.

${ }^{44}$ Новинки: Дїло. Ч. 97. 28 цьвітня. Львів, 1908. С. 4. 
not improve. Anna, his daughter, mentions: "Daddy was lying on the bed, or sitting, wrapped in a blanket, in a comfortable chair. His disease altered face, it was pale, his eyes were even sadder. He complained of pain in his hands and asked me to straighten them. When my efforts failed, he complained that spirits did $\mathrm{it}^{45}$. Due to the poor condition of the scholar, he was helped by friends, scientific institutions and the press. In particular, "The Dilo" appeared under the heading "For the sick writer". It declared the amount of donations collected for the treatment. According to "Novelties", the newspaper of April 21 and May 2, 1908 were among the first benefactors were: acquaintances, friends and others ${ }^{46}$.

M. Hrushevskyi also reported about the grave condition of I. Franko on the pages of "The Literary-Scientific Herald" of April 30, 1908, noting that "On the second day after his arrival to Lviv he was placed in a lunatic asylum. After a few days there were symptoms of improvement, reassurances, which gave the doctors the reason to expect the recovery; but these useful acts then ceased. The consciousness is incomplete: the ill turns to the mischievous ideas that have captured him. Therapeutic treatment has begun, in just a few weeks it will be possible to know if it succeeds" $"$. Due to the fact that the funds for the maintenance and treatment of Franko began at the sanatorium, on the initiative of M. Hrushevskyi, the department of the Scientific Society of T. H. Shevchenko "succeeded with private letters to the people known that Dr. Franko was brought to the city, and for this purpose from Galicia it was got above 2,000 crowns, while from russian Ukraine above 1000 rubles". Further M. Hrushevskyi emphasizes that further collected "money for this purpose in Ga;icia should be sent to the Regional Credit Union in Lviv (booklet 5000) and in Russia to the Lit.Scientific Herald". Concluding his post, he optimistically emphasizes: "We hope that a strong organism, in the good circumstances of the sanatorium, will overcome the illness, and the spiritual strength of our highly respected employee will return!"48.

45 Франко-Ключко А. Іван Франко і його родина... С. 142.

46 Новинки: Дїло. Ч. 90. 21 цьвітня. Львів, 1908. С. 4.; Новинки: Дїло. Ч. 101. 2 мая. Львів, 1908. С. 4.; Новинки: Дїло. Ч. 143. 20 червня. Львів, 1908. С. 4.

${ }^{47}$ Грушевський М. Недуга д-ра Івана Франка... С. 405.

${ }^{48}$ Там само. С. 406. 
The hopes of M. Hrushevskyi come true: in the late summer, I. Franko felt better a little. This news was told by "The Dilo" newspaper on August 1, 1908, in a small note: "We can now share the good news with our entire community. The pride of our people, a prominent worker in our spiritual life, Dr. Ivan Franko, feels better that he has already left the sanatorium and remains at home. Honorable convalescent has already taken to his literary work" ${ }^{\prime 9}$. The newspaper further reports that Ivan Franko is still unable to write his own works, and this work is done for him by his sons. Wishing the scholar fruitful work, the journal emphasized that "In this case, however, our citizenship on both sides of the border should not forget for a moment that the longing of the [renowned] writer and his further health depends mainly on him not being imprisoned for continuous, depleting labor on his daily bread. The news of Dr. Franko's ailment will be the contagion of the best dementi low remarks about his personality, made about ailments by low souls in the Moscow press and the reptilian press" ${ }^{30}$.

About the improvement of Franko's health also reported Kiev magazine "The Rada" in the fall. It contained a publication titled "To the state of Dr. Ivan Franko's Health", which was caused by the readers' letters with questions about I. Franko's well-being and health ${ }^{51}$. The note said that at the end of August, the scholar was able to leave with his family to Ivan Kuziv in the village of Didyovo in Turchansk county. A week later, his wife with his younger son and daughter returned to Lviv, and he with his two older sons stayed for another week. His acquaintances advised him to take care of his health, to go, for example, "to Lindenwiese on Schleszk", to be treated by "electrification", etc., but he "did not find a willingness to go anywhere", since after his trip to a priest I. Kuziv his state of health improved somewhat and he considered himself ".. healthy, only he cannot own his hands, but nobody will help him with this" ${ }^{, 52}$. Also, the newspaper reported that I. Franko "from time to time goes out to the city, visits friends, can do easier work; now he ends up with prypovidky, continues his "Apocrypha" slowly, is going to

${ }^{49}$ Новинки: Дїло. Ч. 171. 1 серпня. Львів,1908. С. 4.

50 Там само.

51 До стану здоровля д-ра Ів. Франка: Рада. Газета політична, економічна і літературна. К., 1908. № 218. 24 сентября (7 листопада). С. 1.

52 Там само. С. 2. 
dictate comments on carols, etc". However, according to "The Rada", paralysis of hands prevented him from doing all this on his own, so he had to dictate to his sons, and they already wrote for him ${ }^{53}$.

Concerning the collection of money for treatment, controversial articles of contemporaries began to appear in the press, which with their content proved to the people that Ivan Franko deserved for his whole work a gift, not a donation. Specifically, on October 24 the newspaper "the Rada" on its pages put a note entitled "Collections for the ill writer", whose author was Lozynskyi. It mainly focuses on I. Franko in the context of the legend of Alfonso Dode about a man with a "golden brain". Further, the author fervently opposes the notion of "Collections for the Ill Writer", asking why it cannot be "A National Gift for Ivan Franko". Concerning this point M. Lozynskyi notes: "The lowest state employee would have deserved for himself the peace and security for the last days of his life! What about him? Deserved "Collections for the Ill Writer...". For thirty year service to 30 million Ukrainian people! A son of Adam Mickiewicz, a gray-haired grandfather, was given a life time pension by the Galician Seim. An ordinary man, only Adam Mickiewicz's son. However, we do not have Seim. But there is a 30 million people, but there are people's institutions, but there are people who constitute them of the tens and hundreds of thousands. And he was the glory of the people, the support of his literary and scientific institutions, and those people who number them in the tens and hundreds of thousands were his acquaintances, friends and comrades, his students and admirers" $" 54$.

Concluding his post, M. Lozynskyi indignantly emphasized: "Alms - and - Ivan Franko! We understand that these words cannot stand by themselves. But we were not able to cross out the word "alms" and put in the place something else that was worthy of the name of Ivan Franko - we crossed out the name of Ivan Franko and put in this place: "the ill writer". But we must understand that it is not worthy of us. It is a good idea to strike out as soon as possible "collections for the ill writer"

53 Там само.

54 Лозинський М. Складки на хорого письменника: Рада. Газета політична, економічна і літературна. К., 1908. № 243. 24 октября (5 грудня). С. 1. 
and to put something that is worthy of the name of Ivan Franko and worthy of us ${ }^{55}$.

In the context, we note that in the second half of the first decade of the twentieth century I. Franko was in a severe financial crisis and did not even have the means to keep his house and bring his sons to university. Therefore, in the fall of 1906 he intended to sell his NSS (National Society of Shevchenko) library, as he said in his letter to his head: “... I do not see an opportunity to keep a house further and pay taxes and bank interests... I must eliminate my interest with the house at the same time the library. I collected it during the difficult times of my life and rejoiced in the hope of giving it the whole to NSS. Now I see that beggars cannot make such gifts, and I turn to you to the head of the Society with the question: Would you consider it possible the Society will buy this library? As for the price, I do not put any amount, let the Society delegate somebody who knows, and let them evaluate how they know"56. But Franko never realized his plan.

Two years later, in the fall of 1908, V. Hnatyuk, seeing that I. Franko needed considerable funds for treatment, reminded him of the intention, but received a negative answer. The scholar said that he was not going to die, and therefore did not see the need to sell the library, because he wants to work more and because of this he will need books ${ }^{57}$.

At this time, Franko did not stop fighting with his illness. To make his hands work, he tried different real and sometimes illusory methods, and with perseverance and imagination tried all the means. One of them is learned from the memoirs of D. Doroshenko, who wrote that Ivan Franko also carried with him a jar filled with a solution of creosote to divert the pursuit of ghosts whom he considered to be the main culprits of his illness, sprinkling around himself. He seemed that the ghosts varnished in that way. Creosote cankered his fingers, his skin cracked and licked, bundles of hands were a kind of red scary wound"58.

55 Там само. С. 1-2.

56 Франко І. Лист до М. С. Грушевського від 27 жовтня 1906 р.: Франко I. Зібр. тв. Т. 50. С. 299.

${ }^{57}$ Мельник Я. Бібліотека Івана Франка: Бібліотека Івана Франка. Науковий опис. У чотирьох томах. К., 2010. Т. І. С. 28.

58 Дорошенко Д. Останній побут Івана Франка у Київі (Сторінка із спогадів): Літературно-науковий вістник. Львів, 1926. Т. ХC. Кн. VII - VIII. За Липень Серпень. С. 282. 


\section{Ivan Franko and Lovran}

In the spring of 1909 I. Franko continued the treatment - another Croatian resort Lovran in a famous local doctor, Doctor of Medicine, University of Vienna A. Eder (born in Vienna in 1859 - died in Bristol in 1916), who headed the sanatorium here from 1909 to $1916^{59}$. But before that, on February 8 , 1909, the Chronicle "The State of Health of Dr. Ivan Franko" appeared in "the Dilo" newspaper which stated: "In the health of Dr. I. Franko was a change that there is the need to leave Lviv. On February 1, the patient with his son Andrew left and stopped just in Fiumum, where the weather is pretty good now. He intends to stay there for a month, and if the weather changes, then he plans to go to Italy"60.

However, Franko's plans were somewhat different from what we can learn from his letter to V. Domanitskyi. As early as April 1, 1908, he wrote: "I would like to spend a few more weeks on the shore of the Adriatic sea, in Abaciya or in Lovran, where our writer Nadiya Kybalchych, married Kozlovska, lives with her ill husband, a wonderful person, whom I wanted to get to acquainted closer" ${ }^{\prime \prime 1}$. The intentions of I. Franko came to fruition almost a year later, as we learned from the newspaper "the Galichanin" of February 11, 1909: "Dr. Ivan Franko is presently in Lovran [and] over the Adriatic sea. His health is improving" $" 62$.This information was confirmed by the subsequent issue of "the Dilo" newspaper, in which on February 20, 1909, it was reported that "Dr. Ivan Franko is now, as we are told, over the Adriatic Sea in Lovran, the Central Hotel. The ill writer, whose health is improving every day, is helped by his son Andrew" $"$.

${ }^{59}$ Simper S. A century of health and sea bathing tourism in Lovran: one hundred zears from issuing the first therapz regulations (1909-2009): Acta med-hist Adriat. Lovran, 2009. № 7(1). S. 145-148.

${ }^{60}$ Новинки. Стан здоровля д-ра Івана Франка: Дїло. Ч. 28. 8 лютого. Львів, 1909. C. 3.

61 Франко І. Лист до В. Доманицького від 2 квітня 1908 р. $з$ Липика... C. $187-188$.

${ }^{62}$ Всячина: Галичанинъ. Львовъ, 1909. 11(24) февраля. С. 3.

${ }^{63}$ Новинки. Д-р Іван Франко ...: Дїло. Ч. 37. 20 лютого. Львів, 1909. С. 4. 


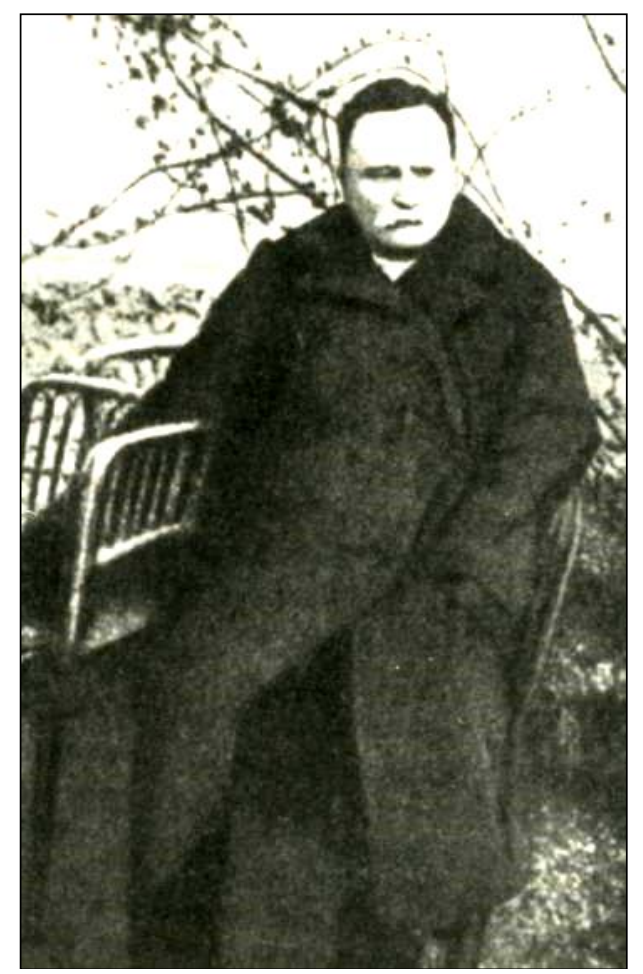

\section{Ivan Franko during the treatment in Lovran. Early March - early April 1909}

The first days of his stay in Lovran Franko had a positive effect on his health. As we can see, there are notes in the press and the words of his son Andryi, who wrote to K. Bandrivskyi on February 22, 1909: "I hope that in a short time Dad's hands are completely straightened... Dad thinks to stay here for a month and a half. If Dad's are straightened up even sooner, we would return to Lviv before time". A. Franko also comforted K. Bandrivskyi with another pleasant news: "Everything that Dad used to say about spirits is now slowly disappearing", 64 .

But despite the good news, we also see the anxiety of Franko's son and the worries of paternal health. In particular, he notes that "Dr. Eder ascertained the atrophy in his hands as a result of the improper circulation of blood, which had already been eliminated in part... The trouble is that the father now has a very large appetite for wine (Portwein) and to dishes with sugar. Dr. Eder explained to Mrs. Romanchukova [a keeper of the Central Hotel], due to her advise

${ }^{64}$ Франко А. Лист до К. Бандрівського від 22 лютого 1909 р. з Ловрана. І. Л. Ф. 3. Спр. 2490. С. 65. 
dad applied for help to Dr. Eder, that wine and sugar can cause his death. And it is only with such distress that I and Mrs. Romanchukova are able to deprive my dad from wine and sugar" ${ }^{\text {"65 }}$.

It should be noted that Lovran, where I. Franko was treated, in his article "From the Adriatic coast" N. Kybalchych states, is distinguished by a gentle climate, healing springs, a play of bright colors, tall old houses that were erected in stone which had the ability to shimmer in the sun with light blue, and in the shade with dark blue, light green chestnut leaves against a background of red earth, and finally with beauty of local streets along which "two can not go side by side, and the other, the socalled broad, walking, reaching the walls with both hands".

In spite of this, the life in Lovran passed monotonously, reminding the life of Ukrainian small county towns or large towns. The inhabitants of Lovran in general belonged to the typical bourgeoisie, among whom the shopkeepers, the owners of villas, houses and vineyards were distinguished ${ }^{66}$.

Lovran itself is very old, since it originated from the historical Roman family Agrippa, who built a summer house here. The name of this city was derived from the fact that its hills were covered with dense laurel forests. According to P. Karmanskyi, "Lovran" of I. Franko's time "counts with about 4,000 inhabitants belonging to it Ica, San Francesco, Olwitz and Tulisevitz, of which some, especially the local "aristocracy" are Italians, and democracy, that is, further nooks, workers and fishermen, make up Croats ... Italians, although they are in the minority, feel the masters, neglecting their neighbors, Slavs, mock at their songs and sometimes come to antagonisms that lead to beatings. Proud Italians go over the sea shore, singing a song proudly: "Nostra terra italianaPorta nome di Lovrana" - but in the meantime in the local church - as a taunt, see lonely anomaly in the Roman church, Mass is served by live Croatian language ....67.

${ }^{65}$ Там само. С. 65-66.

${ }^{66}$ К[ибальчич] Н. 3 побережжя Адріатики. Lovrana: Рада. Газета політична, економічна і літературна. К., 1908. № 67. 20 марта (2 квітня). С. 1.; К[ибальчич] Н. Побережжя Aдріатики. Lovrana. II.: Рада. Газета політична, економічна i літературна. К., 1908. № 99. 30 апріля (13 травня). С. 3.

67 Карманський П. Льоврана: Дїло. Ч. 126. 8 червня. Львів, 1908. С. 1. 
Typical for Lovran at the time was that the "foreigners" came here from the farthest countries for two seasons: spring, which lasted from February to May, and summer, which included the period from July to October. First of all, the climate was more appealing to tourists than Abaci. The average annual temperature in Lovran was $+14^{\circ}$ Celsius. Snow was rare, winter temperatures almost never dropped to zero, and on the contrary, sometimes rising to $+18^{\circ}$ Celsius. Lavran water contains many mineral particles, of which $30 \%$ is salt. The air, on the one hand, is filtered by the sea, and on the other by the scents of the mountain flora. The greatest pride of that time was pension "Central" with the adjacent "Villa Najade", which were on the sea shore under the "council of pleasant hostess Mrs. Romanchukova"68.

It was here, in the villa "Central", that the Frankos found apartment, as it is evidenced by the letters sent from there by Franko to N. Kybalchych ${ }^{69}$. The first letter from Lovran to N. Kybalchych I. Franko sent on 2 March, 1909. It said that already passed a year from the time that he saw her in Lviv. According to him, this year was the worst in his life and was spent "among such patience and anguish and full of such strange adventures that may not be destined for anyone in the world to experience" ${ }^{30}$. The author further writes that he has given by the Almighty to get out of this grief healthy, and he is the first time for the whole year hopes for a "decisive turn for better". The addressee emphasizes that he cannot tell all the details of what happened to him, but only mentions that "spent last March and April in Lypyk in Croatia" he intended to come to N. Kybalchych after treatment in Lovran. Prevented it the adventure that happened to him on April 21, 1908 in Lypyk and as he classifies it "a terrible catastrophe" for himself, as it ended for him "three month disease, three-month compulsory lying in one of Lviv's establishment for incurable patients, and lying ended with complete paralysis of both his hands. From that time, the scholar points out, he was in so much trouble that he was forced to leave from

${ }^{68}$ Там само.

${ }^{69}$ Франко І. Лист до Н. К. Кибальчич від 2 березня 1909 р. з Ловрана «Villa Central»: Франко I. Зібр. тв. Т. 50. С. 368.; Франко І. Лист до Н. К. Кибальчич від 9 березня 1909 р. з Ловрана «Villa Central»: Франко I. Зібр. тв. Т. 50. С. 370.

70 Франко І. Лист до Н. К. Кибальчич від 2 березня 1909 р. з Ловрана «Villa Central»: Франко I. Зібр. тв. Т. 50. С. 368-369. 
February, 1909 "to save his health and ended up in Lovran"71. Ivan Franko finished the story with some considerations about N. Kybalchych' literary activity and stated that he would be very glad when she wanted to write him a few words ${ }^{72}$.

The answer was not delayed. N. Kybalchych wrote to I. Frankov in Lovran on March 6, 1909. She sincerely thanked about the letter and remarked: "I would very much like to talk to you and regret that it can not be done in letters, especially since I cannot write them" ${ }^{, 73}$. The author further emphasizes that I. Franko is being very lacked in Ukrainian literature and hopes that he will fully regain his strength "in quiet and good Lovran,"74.

Also N. Kybalchych tells I. Franko about her collaboration with the journal "The Future", the editorial board of which often disagrees with her thoughts ${ }^{75}$. As for her collaboration with "the Literary and Scientific Bulletin", she notes that after returning her unpublished manuscripts, she does not consider herself an associate. The writer further writes: "It is difficult for me because I have been writing there for more than eleven years and have got used to it" 76 .

In concluding her letter, the author asks I. Franko how much time he will spend on treatment in Lovran and notes that sometimes she writes a lot and sometimes does nothing: "Sometimes life is so depressing that Iu do not have to go for literature. Thus, if I have nowhere to print, what is the reason of writing all the manuscripts or burn them. Better let them burn unwritten in my soul",77.

The scholar did not advised N. Kybalchich to cooperate in the journal "The Future", because he considered his editor and assistants insufficiently experienced for such work and said that the newspaper: "utterly frivolous and issued by people completely immature and unprepared for what they have to do and issued too much without any express program". But despite the comments he made, he emphasized:

\footnotetext{
${ }^{71}$ Там само. С. 369.

72 Там само.

${ }^{73}$ Кибальчич Н. Лист до І. Франка від 6 березня [1909] р. І. Л. Ф. 3. Спр. 1630. C. 559.

74 Там само.

${ }^{75}$ Там само. C. 560.

76 Там само. С. 561.

77 Там само.
} 
"I do not mind that you have included your literary works in that journal, although from the first four issues I see that the editorial, apart from the hot words in the editorial correspondence, has little desire to print your works" "78 . I. Franko was very surprised that the editor of "The Literaryscientific Herald" returned N. Kybalchych' manuscripts. He said: "I had a conversation with Prof. M. Hrushevskyi about editing "the Herald" in 1908 and about the outrageous things that were published there throughout the year, and he knows only one thing to say, that nothing better was not sent to him. I do not know what works you sent to him, but I still think that you could not write worse than Lesya Ukrainka, Hotkevych and both Hrushevskyis published there. I think that in such direction as it is, "the Herald can not go long, but I still have no idea how his reform can be accomplished ${ }^{79}$.

Completing the letter, she assures N. Kybalchych that he deeply sympathizes with her difficult life, but at the same time asks in no case to stop the literary work, "even if she has to keep the written works in the author's folder". Summing up, he emphasized: "From what I see now in Galicia and in Ukraine, I get the certainty that our literary production must go up strongly and that soon it will be possible to organize the centers of respectable and solid literary production in Lviv and Kyiv. In that case, I think that your literary works, both printed and non-printed, will find a wider course and will be better paid than ever" ${ }^{\prime \prime 0}$.

In response, N. Kybalchych sent a letter to Ivan Franko, stating: "Dear Sir! Thank you very much for rememvering me. I wish you, as always, the best!"

From the letter of I. Franko to N. Kybalchych dated March 9, 1909, we see that he lacked money for treatment, which was very expensive for him. His friends and colleagues in Lviv knew this. In particular, on April 2, 1909, the editorial board of the newspaper "The Galychanyn" put on its front pages a note already entitled "Honorary Gift for I. Franko", which read: "Ukrainian-Radical Ambassador of the seim Dumka summons in the "Public Voice" the Ukrainian society to collect

\footnotetext{
78 Там само.

${ }^{79}$ Там само. С. $370-371$.

${ }^{80}$ там само. С. 371.

${ }^{81}$ Кибальчич Н. Листівка до І. Франка від [середини березня] [19]09 р. І. Л.
} Ф. 3. Спр. 1630. С. 563-564. 
for the honorary gift of 300,000 rubles presented to the writer Dr. Ivan Franko. The amount can be collected in the way Mr. Dumka made calculations: 30 million people should donate one geler. To send the money to the Ukrainian society and millions of Russians can also be added and, of course, to make Rechnung ohne Wirt" ${ }^{\text {" }}$.

Lviv continued to collect donations for Ivan Franko's treatment. The newspaper "The Dilo" prints another list of benefactors who contributed to a good cause, adding a certain amount in crowns "Myhailo Liskevych, Vienna 6, Pavlo Durbak 20, Yosyp Pavlinskyia 10, H. U. Lviv 1, Olga Shukhevych Tyshkivtsi 10, Teodozij Chychka 2, Dr. Tadei Solovij 50, Branch of the Russian Pedagogical Society, Zbarazh 10, Ivan Ukrainskyi 55.50, Ivan Trush, Lviv 15"83..

Franko remained on treatment in Lovran to mid-April, 1909, on 23 April this year, the newspaper "The Dilo" reported: "As "The Kyivski Visti" inform Dr. Ivan Franko hostes in Kyiv now, who arrived there last week from Lviv. The famous writer of ours is not completely overcome after the grave misery that he had last year. His hands are sparred so that he does not move his fingers at all. Still, he retained a keen interest in science, visiting libraries in Kiev, mainly interested in Slavic philology. The Honorable scholar will stay in Kiev for one more week and then return to Lviv" "84. And three days later, on April 26, the same newspaper in the literary news added that Ivan Franko had recently translated from Latin the famous novel "Amur and Psyche", and this translation will be published in "the Universal Library" in Lviv" ${ }^{85}$. The history of this translation was rather extraordinary. The translation of Apulian story of Amur and Psyche because of the illness of Franko made with the help of his sons. According to Taras Franko, this translation was first made by his brother Andrew. I. Franko himself intended only to make corrections to this translation, but then left this work and began to dictate his own translation, which later came out in print. In this case, the scholar could not be satisfied by Andrew's text

${ }^{82}$ Почетный даръ для Ив. Франка: Галичанинъ. Львовъ, 1909. 2 (15) апр[і]ля. C. 3.

\footnotetext{
${ }^{83}$ Новинки. Для хорого письменника.... Дїло. Ч. 75. 6 цьвітня. Львів, 1909. С. 3.

${ }^{84}$ Новинки. Франко в Київі: Дїло. Ч. 86. 23 цьвітня. Львів, 1909. С. 3.

85 Лїтературні новини: Дїло. Ч. 88. 26 цьвітня. Львів, 1909. С. 4.
} 
because of the "amateurish approach to business". The same was with the Foreword to this book ${ }^{86}$.

\section{CONCLUSIONS}

The Croatian resort towns of Lypyk and Lovran have benefited to I. Franko mainly in the treatment of illness. During his stay, he worked productively. New poetries, translations, works, etc. appeared, although they were of a specific nature. Here he got acquainted with the local colors, which in the future he reflected in his work. Although the scholar returned from Lypyk and Lovran not cured, he did not fall spiritually and continued to fight with his illness, even in strange ways. The relevant in the context will be the words of the contemporary scholar V. Doroshenko, who emphasized that "sick Franko did not stop being a giant, did not stop impressing us with his hard work and productivity. A severe illness that could bring others out of the world in a very short time, although it broke Franko extremely strong physically and mentally, but did not kill him, and he lived and worked for ten whole years and, despite all the aforementioned consequences of the aforementioned illness, gave not one good thing for us. He worked briskly, somehow even feverishly, detailing on each manuscript when exactly he started it and when he finished, as if he wanted to show that he was not ill at all, but healthy and able to work ${ }^{87}$.

\section{SUMMARY}

The study presents the connections of Ivan Franko with the resort towns of Croatia - Lypyk and Lovran. The relevance of this work is conditioned first of all by the fact that since the independence to the present day Croatia foam vpratsyuye from Ukraine in various fields. One and the most important evidence of this is the opening of the monument to Ivan Franko in $\mathrm{L}$ and $\mathrm{n}$ and $\mathrm{k}$ in in March 2011. The Ukrainian community in Croatia was encouraged to take such a step in 1908.

86 Якимович Б. Іван Франко - видавеиь: Книгознавчі та джерелознавчі аспекти. Львів, 2006. С. 459.

87 Дорошенко В. Іван Франко в моӥх спогадах: Гнатюк М. упор. Спогади про Івана Франка. Львів, 1997. С. 405. 
In this view, the study found that the Croatian city of Lypyk became a city of hope for the Ukrainian genius, where he came for treatment and stayed there for about a month. In 1909, Franko was treated in another Croatian resort town - Lovran. Although the scholar returned from them not cured, but still he will not see and hear there, he found a significant reflection in his poetry, literary works and so on.

It was also found that not many letters came from I. Franko from Lypyk and Lovran and vice versa. His correspondents were O. Franko, daughter Anna, doctor L. Kossak, well-known Ukrainian figures of the time - M. Hrushevskyi, V. Domanitskyi, F. Vovk, V. Hnatyuk, and N. Kibalchich. The main topic of correspondence was Franko's illness, but, in general, the information about scientific interests and reflections of the scholar prevailed.

It is proved that while being treated in the mentioned resort towns, Ivan Franko was studying the cultural life of the Croatian people. At the same time, he made extensive use of the achievements of the Slavic science world, tried to develop the traditions of leading Slavic scholars, and offered his model of development and strengthening of UkrainianCroatian relations.

\section{REFERENCES}

1. Всячина: Галичанинъ. Львовъ, 1909. 11(24) февраля. С. 3.

2.Гнатюк В. Франко в Липику: Іван Франко у спогадах сучасників / Упоряд. передмова та примітки О. I. Дея. Львів: Каменяр, 1972. Кн. II. С. 247.

3.Грушевський М. Недуга д-ра Івана Франка: Літературнонауковий вістник. - Львів-Київ: 3 друкарні Наукового Тов. ім. Шевченка під зарядом К. Беднарського, 1908. Т. XLII. Кн. V. За май. С. 405-406.

4.До стану здоровля д-ра Ів. Франка: Рада. Газета політична, економічна і літературна. К., 1908. № 218. 24 сентября (7 листопада). С. 1.

5. Дорошенко В. Іван Франко в моїх спогадах: Гнатюк М. упор. Спогади про Івана Франка. Львів: Каменяр, 1997. С. 402-407.

6. Дорошенко Д. Останній побут Івана Франка у Київі (Сторінка із спогадів): Літературно-науковий вістник. Львів, 1926. T. XC. Кн. VII - VIII. За Липень - Серпень. С. 282-292. 
7. Кибальчич Н. 3 побережжя Адріатики. Lovrana: Рада. Газета політична, економічна i літературна. К., 1908. № 67. 20 марта (2 квітня). С. 1.

8. Кибальчич Н. Побережжя Адріатики. Lovrana. II.: Рада. Газета політична, економічна і літературна. К., 1908. № 99. 30 апріля (13 травня). С. 3.

9. Карманський П. Льоврана: Дїло. Ч. 126. 8 червня. Львів, 1908. C. 1.

10. Кибальчич Н. Лист до І. Франка від 6 березня [1909] $p$. І. Л. Ф. 3. Спр. 1630. С. 559-561.

11. Кибальчич Н. Листівка до І. Франка від [середини березня] [19]09 р. І. Л. Ф. 3. Спр. 1630. С. 563-564.

12. Коссак Л. Лист до І. Франка від 31 березня 1908 р. із Львова. І. Л. Ф. 3. Спр. 50. С. 352-353.

13.Літературні новини: Дїло. Ч. 88. 26 цьвітня. Львів, 1909. C. 4 .

14. Лозинський М. Складки на хорого письменника: Рада. Газета політична, економічна і літературна. К., 1908. № 243. 24 октября (5 грудня). С. 1.

15.Мельник Я. Бібліотека Івана Франка: Бібліотека Івана Франка. Науковий опис. У чотирьох томах. К., 2010. Т. І. C. 9-31.

16. Мельник Я. I остання часть дороги... Іван Франко: 19081916. Дрогобич: Коло, 2006. 439 с.

17. Мочульський М. 3 останніх десятиліть життя Івана Франка (1896 - 1916): Іван Франко у спогадах сучасників. Львів: Книжково-журнальне видавництво, 1956. С. 422-444.

18. Мочульський М. 3 останніх десятиліть життя Івана Франка (1896-1916): Гнатюк М. упор. Спогади про Івана Франка. Львів: Каменяр, 1997. С. 364-393.

19. Мочульський М. Іван Франко: Студї та спогади. Львів, $1938.210 \mathrm{c}$.

20.Новинки. Для хорого письменника...: Дїло. Ч. 75. 6 цьвітня. Львів, 1909. С. 3.

21.Новинки. Д-р Іван Франко...: Дїло. Ч. 37. 20 лютого. Львів, 1909. C. 4.

22.Новинки. Стан здоровля д-ра Івана Франка: Дїло. Ч. 28. 8 лютого. Львів, 1909. С. 3. 
23.Новинки. Франко в Київі: Дїло. Ч. 86. 23 цьвітня. Львів, 1909. C. 3.

24. Новинки: Дїло. Ч. 90. 21 цьвітня. Львів, 1908. С. 4.

25.Новинки: Дїло. Ч. 81. 11 цьвітня. Львів, 1908. С. 3.

26.Новинки: Дїло. Ч. 87. 18 цьвітня. Львів, 1908. С. 3.

27.Новинки: Дїло. Ч. 97. 28 цьвітня. Львів, 1908. С. 4.

28.Новинки: Дїло. Ч.101. 2 мая. Львів, 1908. С. 4.

29.Новинки: Дїло. Ч.143. 20 червня. Львів, 1908. С. 4.

30.Новинки: Дїло. Ч. 171. 1 серпня. Львів,1908. С. 4.

31.Почетный даръ для Ив. Франка: Галичанинъ. Львовъ, 1909. 2 (15) апр[i]ля. С. 3.

32. Франко А. Лист до К. Бандрівського від 22 лютого 1909 р. $з$ Ловрана. І. Л. Ф. 3. Спр. 2490. С. 65-66.

33. Франко I. Епілог: Франко I. Похорон. Поема. Львів: Каменяр, 2008. С. 52-54.

34.Франко I. Епілог: Франко I. Похорон: Франко I. Зібрання творів у 50-ти т. К.: Наукова думка, 1976. Т. 5. С. 87-89.

35.Франко I. Історія моєї хвороби / Публікація Ярослави Мельник: Парадигма / Інститут українознавства НАН України. Львів: Критика, 1998. С. 178-183.

36.Франко I. Історія моєї хвороби: Інституту літератури ім. Т. Г. Шевченка НАН України (далі - І. Л.). Ф. 3. Спр. 185.

37. Франко І. Лист до В. Гнатюка від 10 квітня 1908 р. $з$ Липика/ Публікація Ярослави Мельник: Парадигма. Зб. наук. Праць / Ін-т українознавства ім. І. Крип'якевича НАН України. Львів: Класика, 1998. С. 191-192.

38. Франко І. Лист до В. Доманицького від 2 квітня 1908 р. $з$ Липика / Публікація Ярослави Мельник: Парадигма. Зб. наук. Праць / Ін-т українознавства ім. І. Крип'якевича НАН України. Львів: Класика, 1998. С. 187-188.

39. Франко I. Лист до В. Доманищького від 27 березня 1908 р. з Липика / Публікація Ярослави Мельник: Парадигма. Зб. наук. Праць / Ін-т українознавства ім. І. Крип'якевича НАН України. Львів: Класика, 1998. С. 183-185.

40.Франко I. Лист до Льва Коссака від 31 березня 1908 р. із Липика: Франко І. Зібрання творів у 50-ти т. К.: Наукова думка, 1986. T. 50. C. 352. 
41.Франко І. Лист до М. С. Грушевського від 27 жовтня 1906 p.: Франко I. Зібрання творів у 50-ти т. К.: Наукова думка, 1986. T. 50. C. 299.

42. Франко І. Лист до М. С. Грушевського від [першої половини квітня 1908 р. із Липика]: Франко І. Зібрання творів у 50-ти т. К.: Наукова думка, 1986. Т. 50. С. 355.

43. Франко І. Лист до М. С. Грушевського від 24 березня 1908 р. із Липика: Франко I. Зібрання творів у 50-ти т. К.: Наукова думка, 1986. T. 50. C. 351-352.

44. Франко І. Лист до Н. К. Кибальчич від 2 березня 1909 р. $з$ Ловрана «Villa Central»: Франко I. Зібрання творів у 50-ти т. К.: Наукова думка, 1986. Т. 50. С. 368-369.

45. Франко І. Лист до Н. К. Кибальчич від 9 березня 1909 р. $з$ Ловрана «Villa Central»: Франко I. Зібрання творів у 50-ти т. К.: Наукова думка, 1986. Т. 50. С. 370-371.

46. Франко І. Лист до О. Ф. Франко від 31 березня 1908 р. із Липика: Франко І. Зібрання творів у 50-ти т. К.: Наукова думка, 1986. T. 50. C. 353.

47. Франко І. Лист до О. Ф. Франко від 6 квітня 1908 р. із Липика: Франко І. Зібрання творів у 50-ти т. К.: Наукова думка, 1986. T. 50. C. 353-354.

48. Франко І. Лист до Ф. К. Вовка від 2 квітня 1908 р. $з$ Липика/ Публікація Ярослави Мельник: Парадигма. Зб. наук. Праць / Ін-т українознавства ім. І. Крип'якевича НАН України. Львів: Класика, 1998. С. 189-190.

49. Франко І. Лист до Ф. К. Вовка від 20 лютого 1908 р. із Львова: Франко I. Зібрання творів у 50-ти т. К.: Наукова думка, 1986 . T. 50 . C. 351.

50. Франко I. Перехресні стежки: Франко I. Захар Беркут. Перехресні стежки. Оповідання. К.: Веселка, 2006. С. 177-462.

51.Франко О. Лист до I. Франка від 8 квітня [1908 p.] зі Львова. І. Л. Ф. 3. Спр. 1636. С. 37-38.

52. Франко-Ключко А. Рукописи Івана Франка в Канаді: (Лист із Липика, Югославія, та інше). Вінніпег, 1957. URL: http://library.kr.ua/elib/franko/franko-rukopis.html.

53. Франко-Ключко А. Рукопси Івана Франка в Канаді. 1. Листи: Для Тебе Тату / Упоряд, автор вступної статті й копентарів М. Шалата. К.: Ярославів Вал, 2010. С. 244-250. 
54. Чикаленко С. Іван Франко: (Уривок із споминів): Наша громада. 1926. Кн. 5-6. С. 17.

55.Якимович Б. Іван Франко - видавець: Книгознавчі та джерелознавчі аспекти. Львів: Б. в., 2006. 691 с.

56. Simper S. A century of health and sea bathing tourism in Lovran: one hundred zears from issuing the first therapz regulations (1909-2009): Acta med-hist Adriat. Lovran, 2009. № 7(1). S. 145-148.

\section{Information about the author:} Halyk V. M.

Candidate of Historical Sciences, Senior Lecturer at the Department of World History and Special Historical Disciplines,

Drohobych Ivan Franko State Pedagogical University 46, Lesi Ukrainky str., Drohobych, Lviv region, 82100, Ukraine 